International Journal of Pharmaceutics \& Pharmacology

\title{
Effect of Alcornea cordifolia Aqueous and Methanolic Leaf Extracts against Antituberculosis Drugs Induced Liver Damage in Rats
}

\author{
Effo $K E^{1^{*}}, N^{\prime} D a K^{2}$, Abouna $A D^{2}$, Adehouni $Y A^{1}$, Djadji $A T L^{1}$, Kouakou $S L^{1}$, Irié-N'Guessan $G^{1}$ and \\ Kouakou-Siransy $N G^{1}$ \\ ${ }^{1}$ Pharmacology Department, Clinical and Therapeutic Pharmacy, University of Félix Houphouët-Boigny, Abidjan - Côte d'Ivoire \\ ${ }^{2}$ Laboratory of Pathological Anatomy, University of Félix Houphouët-Boigny, Abidjan - Côte d'Ivoire
}

Article info

Received 01 January 2021

Revised 27 January 2021

Available Online 03 February 2021

*Corresponding author: Effo Kouakou Etienne, Pharmacology Department, Clinical and Therapeutic Pharmacy, University of Félix Houphouët-Boigny, Abidjan - Côte d'Ivoire

\begin{abstract}
The hepatoprotective properties of Alchornea cordifolia, a medicinal plant was studied in hepatotoxicity induced animal model with a high dose of paracetamol or carbon tetrachloride. Knowing that antituberculosis drugs also represent a risk factor for hepatotoxicity, could A. cordifolia play a key role to limit their hepatotoxicity? The objective of this study was to assess the histological changes of antituberculosis drugs in rat livers and their evolution after administration of an aqueous and a methanolic leaf extracts of A. cordifolia and therefore estimate their polyphenol and flavonoid contents.

Rats were divided into three (3) groups: group 1 was treated with isoniazid; group 2 received the combination of isoniazid and rifampicin and group 3 was given the combination of isoniazid, rifampicin and pyraziamide. For each group of rats, the hepatotoxicant was either administered alone or two hours before administration of an aqueous $(200,400$, or $800 \mathrm{mg} / \mathrm{kg})$ or a methanolic (200, 400, or $800 \mathrm{mg} / \mathrm{kg}$ ) leaf extracts of A. cordifolia each day for 10 days. Animals were sacrificed on day 11 and their livers removed for histolopathological analysis. In addition, total polyphenol and flavonoid contents were estimated in both extracts.

Antituberculosis drug combinations caused peliosis lesions, steatosis and hepatocyte necrosis. The liver histology of rats that received extracts after administration of antituberculosis drug combinations showed the ability of extracts to annihilate or alleviate hepatocellular damage caused by such drugs. The methanolic extract, richer in total polyphenols $(0.55 \pm 0.02 \mathrm{mg}$ EGA) than the aqueous extract $(0.35 \pm 0.01 \mathrm{mg}$ EGA) demonstrated a greater hepatoprotective effect.

Thus, according to liver histological analysis, the aqueous and methanolic leaf extracts of A. cordifolia could attenuate the hepatotoxicity induced by antituberculosis drugs in rats.
\end{abstract}

Keywords: Liver damage; Hepatoprotective; Alchornea cordifolia; antituberculosis drugs

\section{Introduction}

The liver is the main organ involved in the metabolism, detoxification and in the excretion of various endogenous and exogenous substances [1,2] and also exposed to numerous drug attacks. Among hepatotoxic drugs, TB drugs represent a major risk because the liver remains the main site of their biotransformation [1]. As 
Citation: Effo KE, N'Da KJ, Abouna AD et al. Effect of Alcornea cordifolia aqueous and methanolic leaf extracts against antituberculosis drugs induced liver damage in rats. Int J Pharm Pharmacol 2021; 5: 151. doi: $10.31531 / 2581-3080.1000151$

free radicals are commonly involved in the mechanisms of aggression, causing hepatic necrosis [1,3,4], administration of antioxidant compounds could contribute in limiting the oxidative damage related to these hepatitis induced drugs.

For the time being, conventional medicine provides very few drugs that could effectively protect liver against hepatitis induced drug, scientific studies were conducted for novel natural hepatoprotective substances. For this purpose, several medicinal plants like Alchornea cordifolia were investigated [5-7] which methanolic and ethanol extracts showed hepatoprotective properties in an hepatotoxicity induced animal model using high dose of paracetamol or carbon tetrachloride [7-9].

Our previous studies demonstrated that the aqueous and methanolic leaf extracts of $A$. cordifolia normalized the biochemical parameters (AST and ALT) of hepatotoxicity disturbed by antituberculosis drugs administration, moreover the aqueous extract exhibited an in vitro antioxidant activity [10-12].

However, this hepatoprotective effect of A. cordifolia leaf extracts was not investigated on liver tissue. The aim of this study was to analyse histological changes of antituberculosis drugs in rat livers and their evolution after administration of the aqueous and methanolic leaf extracts of A. cordifolia and to estimate their polyphenol and flavonoid contents.

\section{Materials}

\section{Plant materials}

This study was carried out on Alchornea cordifolia (Schum. and Thonn.) leaves (Euphorbiaceae), collected from Yakassemé in the department of Adzopé, $75 \mathrm{~km}$ far from Abidjan, (Côte d'Ivoire). A plant voucher specimen (herbarium $\mathrm{N}^{\circ}$ AC 2016) was deposited at the laboratory of Pharmacology. Plant was identified and authenticated by the National Floristic center of Abidjan (Côte d'Ivoire). Fresh leaves weighing $4204 \mathrm{~g}$ were washed and dried for one week in a shaded room at $18^{\circ} \mathrm{C}$ at the laboratory of Pharmacology, faculty of pharmaceutical and biological sciences (University of Félix Houphouët-Boigny). Then, dried leaves weighing $1703 \mathrm{~g}$ were grounded to powder.

\section{Animal materials}

Naïve albino wistar rats of the strain Rattus norvegicus of both sex, weighing between 150 and $250 \mathrm{~g}$ were used for the experiment. They were provided by the animal husbandry of the Laboratory of pharmacology, faculty of pharmaceutical and biological sciences (University of Félix Houphouët-Boigny, Côte d'Ivoire). Animals were maintained in controlled environmental conditions $\left(24 \pm 1^{\circ} \mathrm{C}\right)$ and a 12 -hour dark / light cycle and were allowed free access to food and water ad libitum. They were fed with animal food pellets from a Food Manufacturing Company in Côte d'Ivoire $\left(\mathrm{FACI}^{\circledR}\right)$. Prior to experiment, animals were kept fasted for 12 hours with free access to water.

\section{Chemicals, reagents and solvents}

A wide range of chemicals, reagents and solvents were used for this study namely isotonic saline $0.9 \%$, diethyl ether (Gifrer), distilled water, antituberculosis drugs (Isoniazid (Lupin LTD), Rifampicin (Remedica LTD), Pyrazinamide (Cadila Pharmaceuticals Limited)); formaldehyde, ethanol, toluene, liquid kerosene, Harris hematoxylin, eosin, xylene, lithium carbonate, eukitt, acetified water, phosphomolybdic acid, Folin-Ciocalteu reagent, calcium carbonate, gallic acid, sodium nitrite, aluminum chloride and soda.

\section{Methods}

\section{Extract preparation}

Dried leaf powder of plant (100 g) was macerated for 24 hours in $1 \mathrm{~L}$ of distilled water for the aqueous extract or in $1 \mathrm{~L}$ mixture of methanol-water (70:30) for the methanolic extract. The mixture was filtered on cotton and then on filter paper (WHATMAN). Filtrate was dried in an oven at $60{ }^{\circ} \mathrm{C}$ for 72 hours for the aqueous extract and evaporated using a rotary evaporator for the methanolic extract. Dry residue obtained was scraped off with a spatula and collected in clean flasks and kept at $4{ }^{\circ} \mathrm{C}$ for experiments. This residue was used to prepare stock solutions of the aqueous or methanolic extracts of A. cordifolia. Concentrations used for this study were $80 \mathrm{mg} / \mathrm{ml}, 40 \mathrm{mg} / \mathrm{ml}$ and $20 \mathrm{mg} / \mathrm{ml}$ respectively for doses of $800 \mathrm{mg} / \mathrm{kg}, 400 \mathrm{mg} / \mathrm{kg}$ and 200 $\mathrm{mg} / \mathrm{kg}$ for each type of extract. Experiment doses were determined according to our previous study [12].

Effect of extracts on hepatic lesions induced by antituberculosis drugs 
Citation: Effo KE, N'Da KJ, Abouna AD et al. Effect of Alcornea cordifolia aqueous and methanolic leaf extracts against antituberculosis drugs induced liver damage in rats. Int J Pharm Pharmacol 2021; 5: 151. doi: 10.31531/2581-3080.1000151

This study consisted in inducing hepatotoxicity in laboratory rats using high dose of antituberculosis drugs in different combinations [1,13] for 10 days.

\section{Effect of aqueous and methanolic leaf extracts of $A$. cordifolia alone on liver}

Forty two (42) rats of both sexes were randomly divided into 7 groups of 6 animals each and daily treated with different substances for 10 consecutive days as follows: Group I (negative control) received normal saline; Groups 2, 3 and 4 treated with aqueous extract of A cordifolia (AEAc ) at doses of $200 \mathrm{mg} / \mathrm{kg} / \mathrm{day}, 400$ $\mathrm{mg} / \mathrm{kg} /$ day or $800 \mathrm{mg} / \mathrm{kg} /$ day; Group 5, 6 and 7 were administered the methanolic extract of A cordifolia (MEAc) at doses of $200 \mathrm{mg} / \mathrm{kg} / \mathrm{day}, 400 \mathrm{mg} / \mathrm{kg} /$ day or $800 \mathrm{mg} / \mathrm{kg} /$ day. Substances were given to animals by oral route.

\section{Effect of aqueous and methanolic leaf extracts of $\boldsymbol{A}$. cordifolia on isoniazid-induced liver injury}

Fifty four (54) rats of both sexes were divided into 9 groups of 6 animals each and were daily treated for 10 consecutive days by different substances as follows: Group 1, received normal saline; Group 2 was administered INH (100 mg/kg/day); Groups 3, 4 and 5 were treated with (MEAC) at doses of 200, 400 and $800 \mathrm{mg} / \mathrm{kg} / \mathrm{day}, 2$ hours after administration of INH $(100 \mathrm{mg} / \mathrm{kg} /$ day); Groups 6,7 and 8 received (AEAC) at doses of 200,400 and $800 \mathrm{mg} / \mathrm{kg} /$ day, 2 hours after administration of INH (100 mg/kg/day); Group 9 was treated with silymarin $(100 \mathrm{mg} / \mathrm{kg} / \mathrm{day}) 2$ hours after administration of INH $(100 \mathrm{mg} / \mathrm{kg} /$ day $)$. All animals were given substances through oral route.

Effect of aqueous and methanolic leaf extracts of $A$. cordifolia on hepatic injury induced by the combination of isoniazid and rifampicin

A total of 54 rats of both sexes were divided into 9 groups of 6 animals each and daily treated for 10 consecutive days by different substances as follows: Group 1, was given normal saline; Group 2, received the combination of INH (100 mg / kg / day) + RIF (100 $\mathrm{mg} / \mathrm{kg} /$ day); Groups 3, 4 and 5 were respectively treated with MEAc at doses of 200, 400 and 800 $\mathrm{mg} / \mathrm{kg} /$ day, 2 hours after administration of the combination INH $(100 \mathrm{mg} / \mathrm{kg} /$ day $)+$ RIF $(100 \mathrm{mg} / \mathrm{kg}$ /day); Groups 6, 7 and 8 respectively received AEAc at doses of 200,400 and $800 \mathrm{mg} / \mathrm{kg} / \mathrm{day}, 2$ hours after being given the combination INH $(100 \mathrm{mg} / \mathrm{kg} /$ day $)+$ RIF (100 mg/kg/day); Group 9 was given silymarin
(100 $\mathrm{mg} / \mathrm{kg} / \mathrm{day}), 2$ hours after receiving the combination INH $(100 \mathrm{mg} / \mathrm{kg} /$ day $)+$ RIF (100 $\mathrm{mg} / \mathrm{kg} /$ day). All animals received substances by oral route.

Effect of aqueous and methanolic leaf extracts of $A$. cordifolia on hepatic injury induced by the combination of isoniazid, rifampicin and pyrazinamide

Forty four (54) rats of both sexes were divided into 9 groups of 6 animal each and daily received for 10 consecutive days different substances as follows: Group1, received normal saline; Group 2 was administered the combination INH $(100 \mathrm{mg} / \mathrm{kg} /$ day $)+$ RIF (100 mg/kg/day) + PZA (100 m/kg/day); Group 3, 4 and 5 were respectively given MEAc at doses of 200, 400 and $800 \mathrm{mg} / \mathrm{kg} /$ day, 2 hours after administration of the combination INH $(100 \mathrm{mg} / \mathrm{kg} / \mathrm{day})+\mathrm{RIF}$ $(100 \mathrm{mg} / \mathrm{kg} /$ day $)+$ PZA (100 mg /kg/day); Groups 6, 7 and 8 were respectively treated with AEAc at doses of 200,400 and $800 \mathrm{mg} / \mathrm{kg} / \mathrm{day}, 2$ hours after administration of the combination INH $(100 \mathrm{mg} / \mathrm{kg} /$ day $)$ + RIF (100 mg/kg/day) + PZA (100 mg/kg/day); Group 9 was given silymarin $100 \mathrm{mg} / \mathrm{kg} / \mathrm{day}, 2$ hours after administration of the combination INH $(100 \mathrm{mg} / \mathrm{kg} /$ day $)$ + RIF (100 mg/kg/day) + PZA (100 mg/kg/day). All animals were given substances by oral route.

On completion of 10 days experimentation, animals were sacrificed under diethyl ether anesthesia, livers of all animals were collected, washed with cold saline solution and blotted with filter paper. They were then fixed in a $10 \%$ formalin solution for histological analysis.

\section{Liver histopathological examination}

The histopathological examination was designed for a gross examination of liver whole organ and then performed microscopic examination of liver tissues after staining each cell structure [14]. The histopathological study was carried out as follow: fixation of liver tissue structures by $10 \%$ formalin; macroscopic examination; inclusion in paraffin using an automatic tissue machine; slicing of liver into thin sections of 3 to $5 \mu \mathrm{m}$ using a microtome, then spread on slides; staining of slides with haematoxylin-eosin. Cell changes were considered minimal when they occurred on $1 / 3$ of the observation field, moderate if they occupy half of the observation field, and severe if they occupy more than half of the observation field. 
Citation: Effo KE, N'Da KJ, Abouna AD et al. Effect of Alcornea cordifolia aqueous and methanolic leaf extracts against antituberculosis drugs induced liver damage in rats. Int J Pharm Pharmacol 2021; 5: 151. doi: $10.31531 / 2581-3080.1000151$

\section{Determination of total polyphenols and flavonoids}

Total polyphenol content in extracts was determined by the method of Singleton et al. (1965) [15] using the Folin-Ciocalteu reagent. Whereas flavonoid quantification was done using an adapted method by Zhishen et al. (1999) [16] with aluminium trichloride and soda.

\section{Ethical considerations}

Animals were used according to international ethical principles on animal experiments [17].

\section{Statistical analysis}

The results were expressed as mean \pm SD. Statistical analysis used the Wilcoxon test. The difference between the mean values was considered significant if $p<0.05$.

\section{Results}

\section{Drying and extraction yield}

Fresh weight of leaves was $4204 \mathrm{~g}$ and dry weight of leaves was $1703 \mathrm{~g}$ with a drying yield of $40.51 \%$.
Extraction with $70 \%$ methanol (MEAc) provided 15.96 $\mathrm{g}$ of dried residue for $100 \mathrm{~g}$ leaf powder, giving a drying yield of $15.96 \%$. The dry residue from aqueous extraction (AEAc) was $8.14 \mathrm{~g}$ for $100 \mathrm{~g}$ of leaf powder, with a yield of $8.14 \%$.

\section{Results of histopathological analysis}

Animal liver structures were observed and represented in Figures 1 to 4 . Abnormalities observed were elementary lesions of clarification, ballooning, acidophilic necrosis, peliosis and micro and macrovacuolar steatosis. Table 1 below showed different elementary lesions, we should notice that a same rat liver can associate several lesions at the same time.

\section{Results of histopathological analysis of unintoxicated liver}

Observation of the section of unintoxicated rat liver showed in figure 1a a normal hepatic parenchyma with regular rows of hepatocytes, a portal space and a centrolobular vein.

Table 1: Elementary lesions observed with tuberculosis drugs and total number of livers.

\begin{tabular}{|l|c|c|c|c|c|}
\hline & Clarification & Ballooning & Acidophilic necrosis & Peliosis & Steatosis \\
\hline INH & $1 / 6(16,67 \%)$ & $1 / 6(16,67 \%)$ & $4 / 6(66,67 \%)$ & $2 / 6(33,33 \%)$ & $2 / 6(33,33 \%)$ \\
\hline INH+RIF & $3 / 6(50 \%)$ & $1 / 6(16,67 \%)$ & $3 / 6(50 \%)$ & $1 / 6(16,67 \%)$ & $2 / 6(33,33 \%)$ \\
& & & & & \\
\hline INH+RIF+PZA & $0 / 6(0 \%)$ & $0 / 6(0 \%)$ & $2 / 6(33,33 \%)$ & $3 / 6(50 \%)$ & $2 / 6(33,33 \%)$ \\
\hline
\end{tabular}

\section{Results of extract effects alone on liver histology}

Microphotography of liver sections receiving $A$. cordifolia extracts alone were confined in Figures $1 \mathrm{~b}$ and 1c. They showed a normal liver structure with no particularities.

\section{Histopathology results of isoniazid-intoxicated liver receiving $A$. cordifolia extracts}

Figure 2a showed the microphotography of INH intoxicated liver rats with acidophilic necrosis and inflammatory infiltrate. Sections of INH intoxicated liver rats treated with MEAc at doses of $800 \mathrm{mg} / \mathrm{kg}$ and $400 \mathrm{mg} / \mathrm{kg}$ or AEAc at a dose of $800 \mathrm{mg} / \mathrm{kg}$ were represented in Figures $2 \mathrm{~b}, 2 \mathrm{c}$ and $2 \mathrm{~d}$ and showed normal liver parenchyma. Howerver, the other doses of extracts had no effect on INH-induced hepatocyte lesions in the same way as MEAc at $200 \mathrm{mg} / \mathrm{kg}$, AEAc at $400 \mathrm{mg} / \mathrm{kg}$ and AEAc at $200 \mathrm{mg} / \mathrm{kg}$ with liver microphotography of rats showing micro and macrovacuolar steatosis (Figures 2e and 2f), clarification, sinusoidal dilatation and steatosis (Figures $2 \mathrm{~g}$ ).

Results of histopathology of liver intoxicated by the association isoniazid + rifampicin receiving extracts of A. cordifolia

Observation of the section of INH+RIF intoxicated liver rat showed in Figure 3a a clarification, a moderate 
Citation: Effo KE, N'Da KJ, Abouna AD et al. Effect of Alcornea cordifolia aqueous and methanolic leaf extracts against antituberculosis drugs induced liver damage in rats. Int J Pharm Pharmacol 2021; 5: 151. doi: $\underline{10.31531 / 2581-3080.1000151}$

acidophilic necrosis with trabecular disorganization and hepatocytes associating micro and macrovacuolar steatoses. Microphotographies of sections of INH+RIF intoxicated liver rat treated with MEAc at doses of 800 $\mathrm{mg} / \mathrm{kg}$ and $400 \mathrm{mg} / \mathrm{kg}$ or AEAc at a dose of $800 \mathrm{mg} / \mathrm{kg}$ represented in Figures $3 \mathrm{~b}, 3 \mathrm{c}$ and $3 \mathrm{~d}$, showed a liver structure with regular rows for MEAc $(800 \mathrm{mg} / \mathrm{kg})$, minimal steatosis with MEAc (400 mg/kg) and minimal clarification and ballooning with AEAc $(800 \mathrm{mg} / \mathrm{kg})$. Livers of rats intoxicated with INH+RIF and treated with AEAc (400 mg/kg) or MEAc $(200 \mathrm{mg} / \mathrm{kg})$ showed clarification and ballooning also acidophilic necrosis with trabecular disorganization (Figures $3 \mathrm{e}$ and $3 \mathrm{f}$ ).
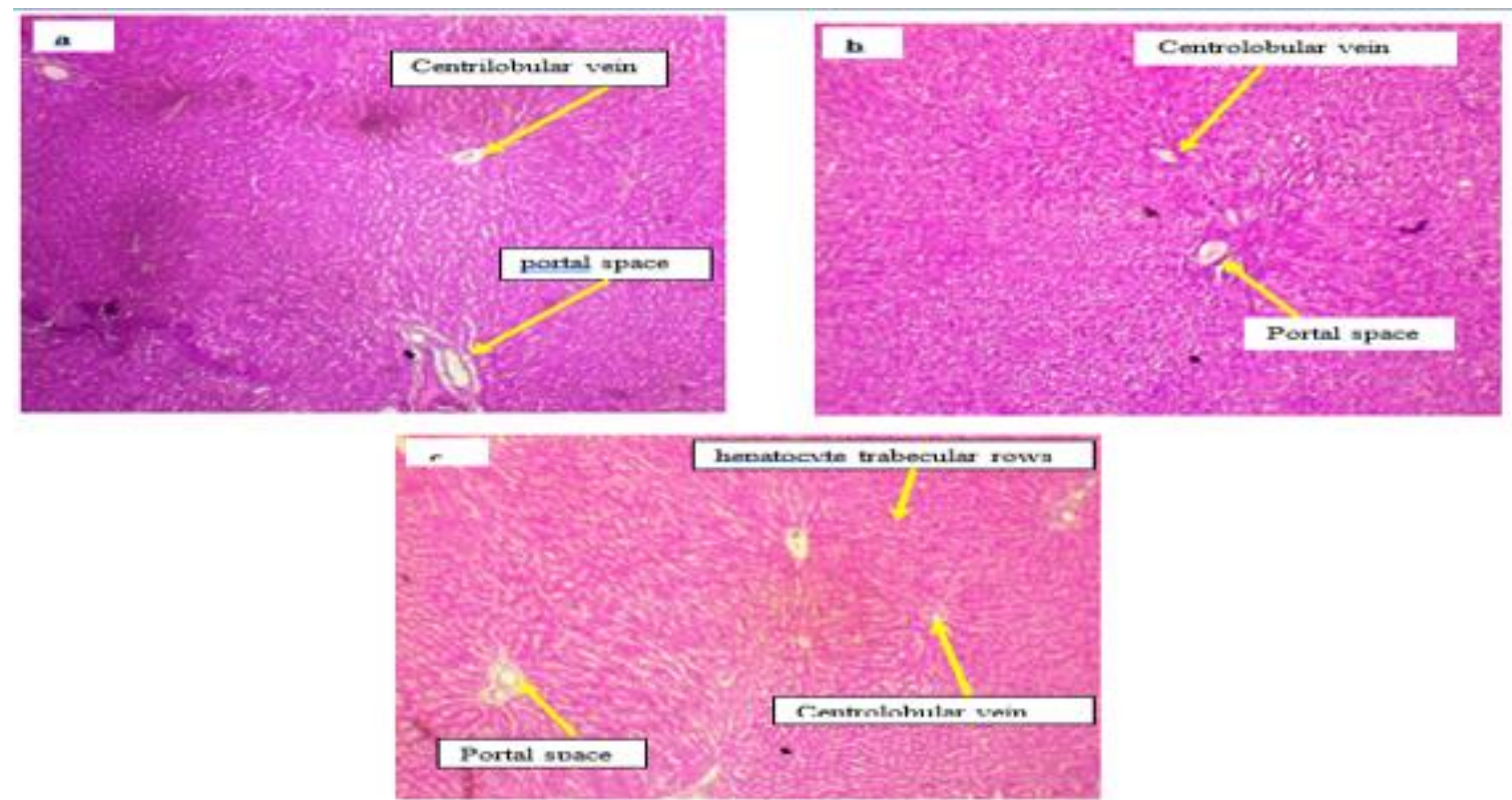

Figure 1: Microphotography of non-intoxicated rat liver by antituberculosis drugs. 1a (HE x 250): Liver of nonintoxicated control rat showing normal hepatic parenchyma with portal space and centrilobular vein; 1b (HE $x$ 250): Liver of rat treated with MEAc $(800 \mathrm{mg} / \mathrm{kg})$ showing normal hepatic parenchyma with portal space and centrilobular vein; 1c (HE x 250): Liver of rat treated with AEAc (800 mg/kg) showing normal hepatic parenchyma with portal space, centrilobular vein and hepatocyte trabecular rows. MEAc: Methanolic extract of A. cordifolia; AEAc: aqueous extract of $A$. cordifolia.

Results of liver histology intoxicated by the combination isoniazid + rifampicin + pyrazinamide and treated by A cordifolia extracts.

Figure 4a showed a section of a rat liver intoxicated by INH+RIF+PZA, exhibiting peliosis, foci of dilated sinus capillaries and acidophilic necrosis. Sections of liver intoxicated with INH+RIF+PZA and treated with MEAc at doses of $800 \mathrm{mg} / \mathrm{kg}$ and $400 \mathrm{mg} / \mathrm{kg}$, AEAc $(800 \mathrm{mg} / \mathrm{kg}$ ) or AEAc (400 mg/kg) were respectively represented in Figures $4 \mathrm{~b}, 4 \mathrm{c}, 4 \mathrm{~d}$ and $4 \mathrm{e}$, showed a dilatation of the centrilobular vein with MEAc at 800 $\mathrm{mg} / \mathrm{kg}$, steatosis with MEAc at $400 \mathrm{mg} / \mathrm{kg}$, peliosis and clarification with AEAc at $800 \mathrm{mg} / \mathrm{kg}$; steatosis and peliosis with AEAc at $400 \mathrm{mg} / \mathrm{kg}$.

\section{Total polyphenol and flavonoid contents}

Total polyphenol content of each extract was expressed in $\mathrm{mg}$ equivalent gallic acid per gram of extract $(\mathrm{mg}$ EGA / g). MEAc contained $0.055 \pm 0.002 \mathrm{mg}$ EGA / g and AEAc contained $0.035 \pm 0.001 \mathrm{mg}$ EGA / g. This difference in value is statistically significant $(\mathrm{p}=0.02)$. The flavonoid content of the aqueous and methanolic extracts of $A$. cordifolia was expressed in mg quercetin equivalent per gram of extract (mg QE/g). MEAc contained $0.054 \pm 0.002 \mathrm{mg} \mathrm{QE} / \mathrm{g}$, and AEAc contained 
Citation: Effo KE, N'Da KJ, Abouna AD et al. Effect of Alcornea cordifolia aqueous and methanolic leaf extracts against antituberculosis drugs induced liver damage in rats. Int J Pharm Pharmacol 2021; 5: 151. doi: $\underline{10.31531 / 2581-3080.1000151}$

$0.048 \pm 0.001 \mathrm{mg} \mathrm{QE} / \mathrm{g}$ with a non-significant difference $(\mathrm{p}=0.06)$.
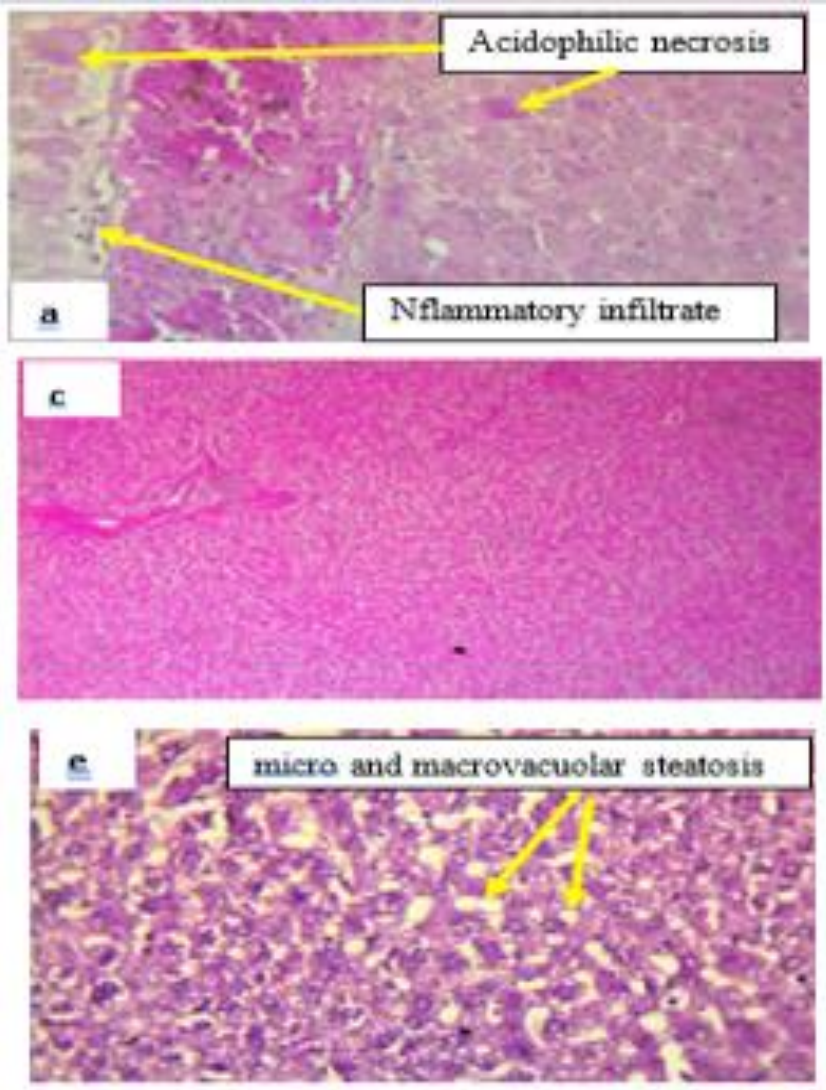
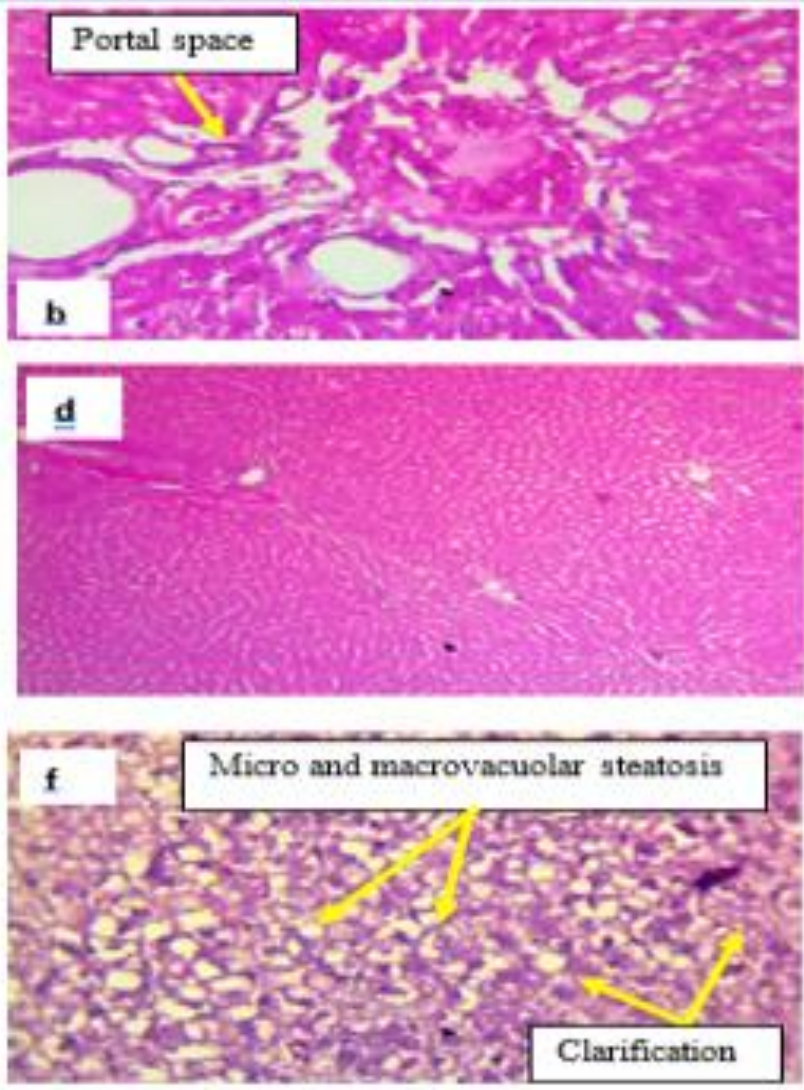

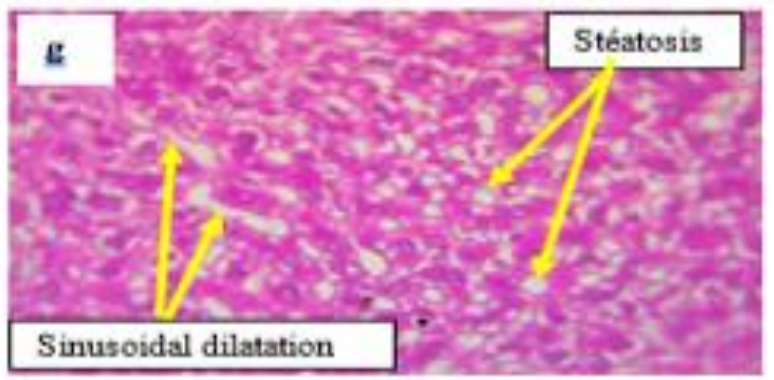

Figure 2: Microphotography of rat liver intoxicated by isoniazid and treated or untreated with extracts. 2a (HE $x$ 400): Liver of rat intoxicated by isoniazid, showing acidophilic necrosis and inflammatory infiltrate; 2 b (HE $x$ 400): Liver of rat intoxicated by Isoniazid and treated with MEAc $800 \mathrm{mg} / \mathrm{kg}$, showing portal space and disappearance of isoniazid-induced necrosis; 2c (HE x 250): Liver of rat intoxicated by isoniazid and treated with AEAc ( $800 \mathrm{mg} / \mathrm{kg}$ ), showing normal structure; 2d (HE x 250): Liver of rat intoxicated by isoniazid and treated with MEAc (400 mg/kg), showing normal structure; 2e (HE x 400): Liver of rat intoxicated by isoniazid and treated with AEAc $400 \mathrm{mg} / \mathrm{kg}$, showing micro and macrovacuolar steatosis; $2 \mathrm{f}$ (HE x 400): Liver of rat intoxicated by isoniazid and treated with MEAc $(200 \mathrm{mg} / \mathrm{kg})$, showing micro and macrovacuolar steatosis; $2 \mathbf{g}$ (HE x 400): Liver of rat intoxicated by isoniazid and treated with AEAC (200 mg/kg), showing sinusoidal dilatation and steatosis; $\mathbf{2 g}$ (HE x 400): Liver of rat intoxicated by isoniazid and treated with AEAc $(200 \mathrm{mg} / \mathrm{kg})$, showing sinusoidal dilatation and steatosis. 
Citation: Effo KE, N'Da KJ, Abouna AD et al. Effect of Alcornea cordifolia aqueous and methanolic leaf extracts against antituberculosis drugs induced liver damage in rats. Int J Pharm Pharmacol 2021; 5: 151. doi: $10.31531 / 2581-3080.1000151$




Citation: Effo KE, N'Da KJ, Abouna AD et al. Effect of Alcornea cordifolia aqueous and methanolic leaf extracts against antituberculosis drugs induced liver damage in rats. Int J Pharm Pharmacol 2021; 5: 151. doi: $10.31531 / 2581-3080.1000151$
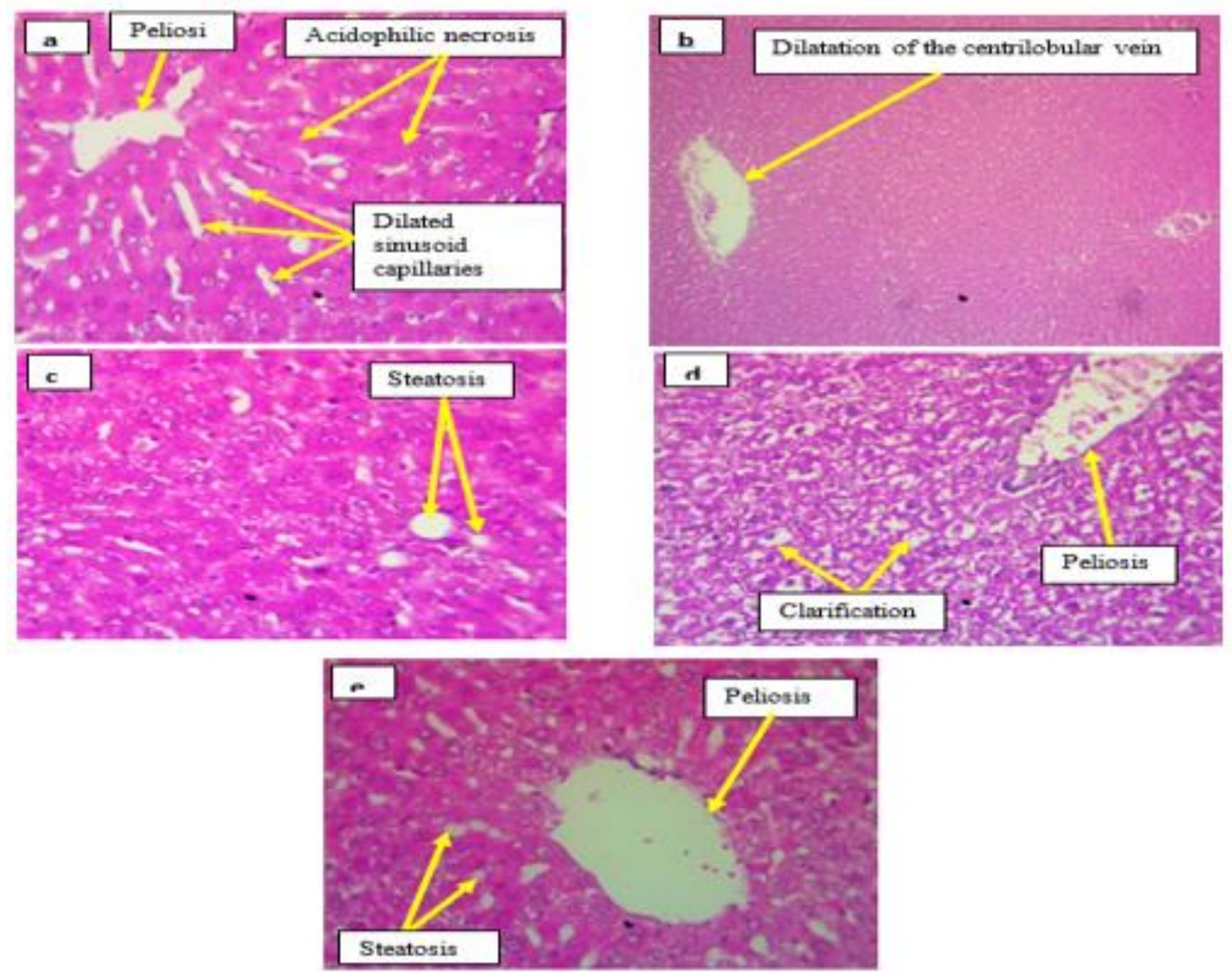

Figure 4: Microphotography of rat liver intoxicated by isoniazid + rifampicin + pyrazinamide and treated or untreated with extracts. $4 \mathrm{a}$ (HE x 400): liver of rat intoxicated by isoniazid + rifampicin + pyrazinamide, showing peliosis, foci of dilated sinusoid capillaries and acidophilic necrosis; $4 \mathrm{~b}$ (HE x 250): Liver of rat intoxicated by isoniazid, rifampicin and pyrazinamide and treated with MEAc $(800 \mathrm{mg} / \mathrm{kg}$ ), with dilatation of the centrilobular vein; 4c (HE x 400): Liver of rat intoxicated by isoniazid, rifampicin and pyrazinamide and treated with MEAc $400 \mathrm{mg} / \mathrm{kg}$, showing steatosis; $4 \mathrm{~d}$ (HE x 400): Liver of rat intoxicated by isoniazid, rifampicin and pyrazinamide and treated with AEAc $800 \mathrm{mg} / \mathrm{kg}$, showing clarification and peliosis; 4e (HE x 400): Liver of rat intoxication by isoniazid, rifampicin and pyrazinamide and treated with AEAc $(400 \mathrm{mg} / \mathrm{kg})$, showing steatosis and peliosis.

\section{Discussion}

Tuberculosis drugs administered in this study were toxic to the liver. Isoniazid caused acidophilic necrosis lesions and inflammatory infiltrate; isoniazid and rifampin caused clarification, acidophilic necrosis, steatosis and trabecular disorganization; and isoniazid, rifampin and pyrazinamide caused peliosis lesions, foci of sinus capillary dilation and acidophilic necrosis. Various animals and human case studies showed that hepatotoxicity induced by the combination of antituberculosis drugs was mainly manifested by hepatocellular steatosis and centrilobular necrosis associated with cholestasis, by covalent binding of drug molecules to cellular macromolecules [18]. Administration of $A$. cordifolia extracts, such as the methanolic extract at doses of $400 \mathrm{mg} / \mathrm{kg}$ and 800 $\mathrm{mg} / \mathrm{kg}$ and the aqueous extract at a dose of $800 \mathrm{mg} / \mathrm{kg}$, reduced damage caused by these antituberculosis drugs as shown in the histopathological study. The methanolic extract, at all doses, prevented isoniazid-induced necrosis lesions and inflammatory infiltrate. As for the 
Citation: Effo KE, N'Da KJ, Abouna AD et al. Effect of Alcornea cordifolia aqueous and methanolic leaf extracts against antituberculosis drugs induced liver damage in rats. Int J Pharm Pharmacol 2021; 5: 151. doi: 10.31531/2581-3080.1000151

aqueous leaf extract of $A$. cordifolia at a dose of 200 $\mathrm{mg} / \mathrm{kg}$, it did not protect the liver. However, at high doses the aqueous leaf extracts of A. cordifolia (400 $\mathrm{mg} / \mathrm{kg}$ and $800 \mathrm{mg} / \mathrm{kg}$ ) combined with isoniazid clearly protected the liver since histological sections did not reveal any lesions. Histopathology images of rat livers treated with isoniazid + rifampicin and methanolic extract $(800 \mathrm{mg} / \mathrm{kg})$ were examined, the hepatocellular lesions disappeared and the hepatocyte trabecular came to normalcy. With the methanolic extract at $400 \mathrm{mg} / \mathrm{kg}$, a minimal steatosis still persists. The methanolic extract at a dose of $200 \mathrm{mg} / \mathrm{kg}$ had no effect on the histological damage caused by the combination of isoniazid and rifampicin. The aqueous extract at a dose of $800 \mathrm{mg} / \mathrm{kg}$, showed a regression of acidophilic necrosis and the microphotography showing only a clarification and ballooning. The other doses of the aqueous extract failed to protect the liver. As for the association isoniazid + rifampicin + pyrazinamide, there was peliosis, acidophilic necrosis and dilatation of sinusoid capillaries which were attenuated by A. cordifolia extracts. Indeed, microphotographies of rat livers treated with the methanolic extract at a dose of 800 $\mathrm{mg} / \mathrm{kg}$ showed only dilatation of the centrolobular vein with resorption of peliosis and acidophilic necrosis. Like the methanolic extract at a dose of $400 \mathrm{mg} / \mathrm{kg}$, showing a disappearance of peliosis and acidophilic necrosis with a persistence of steatosis. The aqueous extract at doses of $800 \mathrm{mg} / \mathrm{kg}$ and $400 \mathrm{mg} / \mathrm{kg}$ did not seem to have protected the liver because liver photomicrographies still show foci of peliosis, clarification and steatosis. However, these extracts administered alone, did not cause necrosis, clarification, ballooning or hepatic steatosis. The microphotography of rat livers that received the extracts alone did not show any biochemical parameter disturbances. The results of this study were in agreement with the study of Jacob et al (2014), [9] in which A. cordifolia attenuated hepatocellular lesions induced by paracetamol at high doses. However, Ajibade and Olayemi (2015) [19] showed that methanolic extract of A. cordifolia, administered alone at doses of $800 \mathrm{mg} / \mathrm{kg}$ and 1600 $\mathrm{mg} / \mathrm{kg}$ for 8 consecutive days, caused hepatocellular damage. However, A. cordifolia is considered to be a plant with a high margin of safety in single administration [20].

Furthermore, during extraction, $70 \%$ methanol was used as for Ajibade and Olayemi (2015) [19] who used pure methanol. The low methanol concentration could explain the non-toxic effect of our extract. The harvest location could back up the non- toxic effect of our extract at $800 \mathrm{mg} / \mathrm{kg}$. Indeed, A cordifolia was harvested for this study in its natural environment in Côte d'Ivoire while Ajibade and Olayemi (2015) [19] harvested it in a botanical garden in Nigeria. It was the same case with the plant studied by Jacob et al (2014) [9] which was harvested in its natural environment on uncultivated agricultural land. Protective effects against hepatocellular damage were observed with the methanolic extract of A. cordifolia at doses of 400 $\mathrm{mg} / \mathrm{kg}$ and $800 \mathrm{mg} / \mathrm{kg}$, as well as with the aqueous extract at a dose of $800 \mathrm{mg} / \mathrm{kg}$. This superiority of activity of the methanolic extract could be partly justified by the higher total polyphenol content in the methanolic extract compared to the aqueous extract. Indeed, the methanolic extract was found to be richer in total polyphenols $(0.055 \pm 0.002 \mathrm{mg}$ EGA $)$ than the aqueous extract $(0.035 \pm 0.001 \mathrm{mg}$ EGA $)$. Studies showed that the presence of polyphenols conferred its antioxidant activity [21]. Manga et al (2004) [22-24] also found that flavonoids had antioxidant activities.

\section{Conclusion}

Histopathological analysis of rat livers that received the aqueous and methanolic leaf extracts of A. cordifolia after intoxication with antituberculosis drug combination, showed extracts ability to annihilate or attenuate hepatocellular damage of antituberculosis drugs. This observed protection against hepatocellular damage was most pronounced with the methanolic extract of A. cordifolia at doses of $400 \mathrm{mg} / \mathrm{kg}$ and 800 $\mathrm{mg} / \mathrm{kg}$, as well as the aqueous extract $(800 \mathrm{mg} / \mathrm{kg})$. This high activity of the methanolic extract could be partly justified by the higher total polyphenol content in the methanolic extract compared to the aqueous extract. Thus, the aqueous and methanolic leaf extracts of $A$. cordifolia significantly reduced hepatotoxicity induced by antituberculosis drugs in rats.

\section{Acknowledgement}

We express our gratitude to the head of department of the pathological anatomy laboratory of the UFR Medical Sciences of Abidjan, Pr Diomandé Mohenou I. Jean-Marie and to all his team, for helping us in carrying out this work.

\section{Conflicts of Interests}

The authors declare no conflict of interest.

\section{Funding}

None declared. 
Citation: Effo KE, N'Da KJ, Abouna AD et al. Effect of Alcornea cordifolia aqueous and methanolic leaf extracts against antituberculosis drugs induced liver damage in rats. Int J Pharm Pharmacol 2021; 5: 151. doi: 10.31531/2581-3080.1000151

\section{References}

1. Santhosh S, Sini TK, Anandan R, et al. Hepatoprotective activity of chitosan against isoniazid and rifampicin-induced toxicity in experimental rats. Eur J Pharmacol 2007; 572: 6973.

2. Akindele AJ, Ezenwanebe KO, Anunobi CC, et al. Hepatoprotective and in vivo antioxidant effects of Byrsocarpus coccineus Schum. And Thonn (Connaraceae). J Ethnopharmacol 2010; 129: 4652.

3. Georgieva N, Gadjeva V, Tolekova A. New isonicotinoylhydrazones with SSA protect against oxidative-hepatic injury of isoniazid. Trakia J Sci 2004; 2: 37-43.

4. Pramod K, Deva RG, Lakshmayya, Ramachandra SS. Antioxidant and hepatoprotective activity of tubers of Momordica tuberose Cogn. against CCl4 induced liver injury in rats. Ind J Exp Biol 2008; 46: 510-513.

5. Olaleye MT, Adegboye OO and Akindahunsi AA. Alchornea cordifolia extract protects wistar albino rats against acetaminophen-induced liver damage. Afr J Biotechnol 2006; 5: 2439-2445.

6. Kouakou-Siransy G, Sahpaz S, N'guessan GI, et al. Effects of Alchornea cordifolia on elastase and superoxide anion produced by human neutrophils. Pharm Biol; 2010; 48: 128-133.

7. Osadebe PO, Okoye FBC, Uzor PF, et al. Phytochemical analysis, hepatoprotective and antioxidant activity of Alchornea cordifolia methanol leaf extract on carbon tetrachlorideinduced hepatic damage in rats. As Pac J Trop Med; 2012: 289-293.

8. Olaleye MT, Kolawole AO and Ajele JO. Antioxidant Properties and Glutathione $\mathrm{S}$ Transferases Inhibitory Activity of Alchornea cordifolia Leaf Extract in Acetaminophen-Induced Liver Injury IJPT; 2007; 6: 63-66.

9. Jacob JM, Olaleye MT, Olugbuyiro JAO. Hepatoprotective effect of Alchornea cordifolia leaf on liver damage in albino rats. Int $\mathbf{J}$ Appl Sci Biotechnol 2014; 2: 217-221.

10. Etienne EK, Landry KS, Geneviève IGA, et al. Hepatoprotective effects of methanol extract of Alchornea cordifolia leaves against anti-tubercular drugs induced hepatotoxicity in rats. Afr J Pharm Pharmacol 2017; 11: 501-508.

11. Effo KE, Kouakou SL, Irie-N'Guessan G, et al. Antioxidant Activity and Hepatoprotective Effect of an Aqueous Extract of Alchornea cordifolia Leaves. Pharmacol \& Pharmacy 2017; 8: 369-380.
12. Effo KE, Kouakou-Siransy G, Irie-Nguessan G, et al. Acute toxicity and antipyretic activities of a methanolic extract of Alchornea cordifolia leaves. Pharmacol Pharm 2013; 4: 1-6.

13. Saraswathy SD, Suja V, Prema G, et al. Effect of Liv. 100 against antitubercular drugs (isoniazid, rifampicin and pyrazinamide) induced hepatotoxicity in rats. Ind J Pharmacol 1998; 30: 233-238.

14. Redman RS, Ball WD, Mezey E, et al. Dispersed donor salivary gland cells are widely distributed in the recipient gland when infused up the ductal tree. Biotech Histochem 2010; 84: 253-260.

15. Singleton VL, Rossi JA. Colorimetry of total phenolics with phosphomolybdic-phosphotungstic acid reagents. Am J Technol and Viticult 1965; 16: 144-153.

16. Zhishen J, Mengcheng $\mathrm{T}$ et Jianming W. The determination of flavonoid contents in Mulberry and their scavenging effects on superoxide radicals. Food Chem 1999; 64: 555-559.

17. Veissier I. Expérimentation animale: biologie, éthique, réglementation. INRA Prod. Anim 1999; 12: 365-375.

18. Tostmann A, Boeree MJ, Aarnoutse RE, et al. Antituberculosis drug-induced hepatotoxicity: Consise up-to-date review. Gastroenterol Hepatol 2008; 23: 192-202.

19. Ajibade TO et Olayemi FO. Reproductive and toxic effects of methanol extract of Alchornea cordifolia leaf in male rats. Andrologia $2015 ; 47: 1034-1040$.

20. OCDE. Système intégré harmonisé de classification des dangers pour la santé humaine et les effets environnementaux des substances chimiques. Organisation de coopération et de développement économiques 1998; Paris, France.

21. Shiney RB, Ganesh P. Phytochemical analysis and comparative effect of Cinnamomum zeylanicus, Piper nigrum and Pimpinella anisum with selected antibiotics and its antibacterial activity against Enterobacteriaceae family. Int J Pharmac and Biol Arch 2012; 3: 914-917.

22. Manga HM, Brkic D, Marie DEP, et al. In vivo antiinflammatory activity of Alchornea cordifolia. J Ethnopharmacol 2004; 92: 209-214.

23. Jahangir MA, Anand C, Muheem A, et al. Nano Phytomedicine Based Delivery System for CNS Disease. Curr Drug Metabol 2020.

24. Muheem A, Jahangir MA, Jaiswal CP et al. Recent Patents, Regulatory Issues and Toxicity of Nanoparticles in Neuronal Disorders. Curr Drug Metabol 2020. 
Citation: Effo KE, N'Da KJ, Abouna AD et al. Effect of Alcornea cordifolia aqueous and methanolic leaf extracts against antituberculosis drugs induced liver damage in rats. Int J Pharm Pharmacol 2021; 5: 151. doi: 10.31531/2581-3080.1000151

This manuscript was peer-reviewed

Mode of Review: Single-blinded

Academic Editor: Dr. Bijaya Kumar Mohanty

Copyright: (92021 Effo KE, et al. This article is distributed under the terms of the Creative Commons Attribution 4.0 International License (http://creativecommons.org/licenses/by/4.0/), which permits unrestricted use, distribution, and reproduction in any medium, provided you give appropriate credit to the original author(s) and the source, provide a link to the Creative Commons license, and indicate if changes were made. 